\title{
Cement chemistry
}

\section{2nd edition}

\author{
H.F.W. Taylor \\ Emeritus Professor of Inorganic Chemistry \\ University of Aberdeen
}

\section{$\overline{\mathbf{I}}$ Thomas Telford}


Published by Thomas Telford Publishing, Thomas Telford Services Ltd, 1 Heron Quay, London E14 4JD

First published 1990 by Academic Press

Thomas Telford edition published 1997

Distributors for Thomas Telford books are

USA: American Society of Civil Engineers, Publications Sales Department,

345 East 47th Street, New York, NY 10017-2398

Japan: Maruzen Co. Ltd, Book Department, 3 Ä10 Nihonbashi 2-chome, Chuo-ku, Tokyo 103

Australia: DA Books and Journals, 648 Whitehorse Road, Mitcham 3132, Victoria

A catalogue record for this book is available from the British Library

ISBN: 0727725920

(C) Professor H.F.W. Taylor and Thomas Telford Services Ltd, 1997

All rights, including translation, reserved. Except for fair copying, no part of this publication may be reproduced, stored in a retrieval system or transmitted in any form or by any means, electronic, mechanical, photocopying or otherwise, without the prior permission of the Books Publisher, Thomas Telford Publishing, Thomas Telford Services Ltd, 1 Heron Quay, London E144JD.

This book is published on the understanding that the author is solely responsible for the statements made and opinions expressed in it and that its publication does not necessarily imply that such statements and/or opinions are or reflect the views or opinions of the publishers. 


\section{Preface}

The previous edition of this book, published by Academic Press in 1990, is both out of print and out of date, and when Thomas Telford invited me to prepare a new edition I was delighted to comply. I am most grateful both to them and to Academic Press, whose release of the copyright made the present edition possible.

This book deals with the chemistry of the principal silicate and aluminate cements used in building and civil engineering. It is directed primarily to those whose background is in chemistry, materials science or related disciplines. Emphasis is placed throughout on the underlying science rather than on practical applications, which are well covered in other works. The cements considered fall into the category of hydraulic cements; they set and harden as a result of chemical reactions with water, and if mixed with water in appropriate proportions continue to harden even if subsequently placed in water. Much the most important is Portland cement. Chapters 1 to 4 deal mainly with the chemistry of Portland cement manufacture and the nature of the resulting product. Chapters 5 to 8 deal mainly with the processes that occur when this product is mixed with water and with the nature of the hardened material. Chapters 9 to 11 deal with the chemistry of other types of cement, of admixtures for concrete and of special uses for cements. Chapter 12 deals with chemical and microstructural aspects of concrete, including ones that affect its durability or limit its service life.

The literature of cement chemistry is voluminous; the abstracting journal, Cements Research Progress, has for some years listed around 1000 new contributions annually. The output of the seven years since the previous edition of this book appeared is reflected in the increased number of references to the literature, which is approximately 1500 compared with 1300 in that edition. Of necessity, coverage in the present book has been selective, but it is hoped that the most important contributions up to mid-1996 have been covered. The advances in some parts of the subject have been greater than in others, and this is reflected in the differences between this and the previous edition; some sections have been totally rewritten whereas others have changed relatively little.

As one who has seen the subject develop over a period of nearly 50 years, I am highly aware of the problems that those entering the subject 
for the first time have in grappling with the previous literature. I have therefore tried not only to deal with recent research, but also to place the development of our knowledge in a historical perspective. I hope that the book will thereby serve both as an introduction that assumes no previous specialist knowledge of cements, and as a guide to further research.

\section{Acknowledgements}

I am most grateful to Sally Smith and her colleagues at Thomas Telford Publishing for their unfailing help and patience, and to my wife, Joan, for help in preparing the reference list and in other ways. I am also most grateful to former colleagues at the University of Aberdeen and friends elsewhere with whom I have had productive discussions over a period of many years. Professor F.P. Glasser was most helpful in suggesting that this edition be published. Others in Aberdeen to whom thanks are due include, notably, Dr J.A. Gard, Dr L.S. (Dent) Glasser and Dr E.E. Lachowski. Either indirectly through the previous edition, or directly in relation to the present one, many others have given invaluable assistance. Mr R.S. Gollop, Dr S. Kelham, Mr C.P. Kerton, Dr G.R. Long, Mr J.S. Lumley, Dr J.J. Kollek, Dr G.K. Moir and Mr M.S. Sumner, now or formerly of Blue Circle Industries plc, helped on many aspects of cement production, use and durability. My thoughts on the hydration chemistry of calcium silicates owe much to discussions with Drs P.W. Brown, G. Frohnsdorff and H.M. Jennings, then all at the National Bureau of Standards (now NIST), USA. Those on microstructural aspects of hydration similarly owe much to discussions with the late Professor P.L. Pratt and Dr K.L. Scrivener, then both at Imperial College, London. Dr L.J. Parrott (British Cement Association) helped greatly with a discussion on the pore structures of cement pastes. Drs A. Capmas, C.M. George, K.L. Scrivener, D. Sorrentino and F. Sorrentino (Lafarge Corporation) gave extensive and invaluable help in preparing the section on calcium aluminate cements. Professor J. Bensted, then at The British Petroleum Company plc, corrected some important errors on oil well cementing. Many of those mentioned above gave help that included comments on parts of the manuscript, but any errors are mine.

Many people, noted in the reference list, generously made results available in advance of publication. Dr D.C. Pomeroy, formerly at the British Cement Association, Drs K.L. Scrivener and M.C. Lewis (Imperial College) and Dr D. Sorrentino kindly provided some excellent light or electron micrographs. Mr C.P. Kerton freely gave extensive bibliographical assistance, and I thank Mr S. Black and Ms J. Kerr (University of Aberdeen) for photography of the line drawings.

I thank publishers (as copyright holders; italics) and authors for permission to reproduced the figures noted below. Authors and sources, including copyright years, are given in the captions and reference list and, where it was requested, the acknowledgment is expanded below. Reprinted by permission of the American Ceramic Society, Figs 5.5C and D (Ref. J11, Issue 10, Oct., on 'Morphological development of hydrating tricalcium silicate as examined by electron microscopy techniques'); Fig. 5.1 (Ref. M46, Issue 12, Dec., on 'Analytical electron 
microscopy of cement pastes: IV, $\beta$-dicalcium silicate pastes'); Figs 5.7 and 5.9 (Ref. T21, Issue 6, June, on 'Proposed structure for calcium silicate hydrate gel'); Fig. 5.12 (Ref. J16, Issue 8, Aug., on 'Aqueous solubility relationships for two types of calcium silicate hydrate'); Fig. 9.3 (Ref. T39, Issue 12, Dec., on 'Analytical study of pure and extended Portland cement pastes: II, fly ash- and slag-cement pastes'). American Concrete Institute, Fig. 11.6. Reprinted by permission of American Journal of Science, Fig. 6.5. British Cement Association, Fig. 5.11. (C) (British) Crown Copyright 1970. Published by permission of the Controller of HMSO, and with thanks to the Institute of Materials, Fig. 2.9. Cemento, Fig. 11.4. Chapman and Hall Ltd, Figs 10.2 and 10.6. Reprinted from 'Cement and Concrete Research', with kind permission from Elsevier Science Ltd, The Boulevard, Langford Lane, Kidlington OX5 1GB, UK, Figs 1.2, 3.3, 5.4, 5.8, $5.14,5.15,8.9,11.1,11.5,12.5$ and 12.7. International Cement Microscopy Association from 'Proceedings of the 6th International Conference on Cement Microscopy, Albuquerque, NM, USA', Fig. 4.3. 8th International Congress on the Chemistry of Cement (Vol. 3, Fig. 4, p. 231), Fig. 6.7. Materials Research Society, Figs 9.1, 9.2 and 12.1. R. Oldenbourg Verlag, Fig. 5.6. Palladian Publications Ltd., Fig. 7.1. RILEM Publications, first published in 'The hydration of tricalcium silicate', RILEM committee 68-MMH, task group 3, 'Materials and Structures' 17, (102) 458 (1984), Figs 5.10 and 5.13. The Royal Society, Fig. 7.7. Editions Septima, Fig. 10.7. Society of Chemical Industry, Fig. 5.2. Stroyizdat, Fig. 3.4. Thomas Telford Publishing, Figs 12.4 and 12.6. Transportation Research Board, National Research Council, Washington, DC, Fig. 4, p. 380 in Ref. L35, 'Changes in composition of the aqueous phase during hydration of cement pastes and suspensions', Fig. 7.8. Reprinted by permission of John Wiley and Sons Ltd, Fig. 8.4. I thank the National Bureau of Standards (now NIST) for the use of Figs 7.9 and 8.2. Figs 7.2, 8.8, 10.1,11.3, 12.2, 12.3, 12.7, 12.8 and 12.9 did not appear in the previous edition of this book. The remaining figures were used in that edition, and I am most grateful to Academic Press for permission to reproduce them. 


\section{Contents}

1 Portland cement and its major constituent phases 1

1.1 Introduction

1.1.1 Portland cement: general 1

1.1.2 Types of Portland cement 2

1.1.3 Cement chemical nomenclature and other abbreviations 3

1.2 Alite 4

1.2.1 Polymorphism and crystal structure 4

1.2.2 Tricalcium silicate solid solutions 7

1.2.3 Compositions of alites in clinkers 7

1.2.4 Polymorphic modifications of the alites in clinkers 9

1.2.5 X-ray powder patterns and densities of tricalcium silicate and alites

1.2.6 Optical, thermal and other data 13

1.3 Belite 13

1.3.1 Polymorphism and crystal structure 13

1.3.2 Polymorphic forms and textures in clinker belites 16

1.3.3 Compositions of belites in clinkers 18

1.3.4 Cell parameters, X-ray powder patterns and other data 18

$\begin{array}{ll}1.4 \text { Aluminate } & 19\end{array}$

1.4.1 Crystal structure: cubic, orthorhombic and monoclinic modifications 19

1.4.2 Other modifications 21

1.4.3 Structural modifications of clinker aluminates 22

1.4.4 Compositions of clinker aluminates 23

1.4.5 X-ray powder data, densities and optical properties 24

1.5 Ferrite 24

1.5.1 Crystal structure and composition in the

1.5.2 Compositions of clinker ferrites 26

1.5.3 Crystal data and X-ray powder patterns for ferrites containing substituent ions $\quad 27$

1.5.4 Optical, magnetic and other data 28 
2 High-temperature chemistry 29

2.1 Introduction 29

2.2 Systems containing $\mathrm{CaO}$ with $\mathrm{SiO}_{2}$ or $\mathrm{Al}_{2} \mathrm{O}_{3}$ or both 29

2.2.1 The $\mathrm{CaO}-\mathrm{SiO}_{2}$ system 29

2.2.2 The $\mathrm{CaO}-\mathrm{Al}_{2} \mathrm{O}_{3}$ system 30

2.2.3 $\mathrm{C}_{12} \mathrm{~A}_{7}$ and derived structures 31

2.2.4 $\mathrm{C}_{5} \mathrm{~A}_{3}, \mathrm{C}_{2} \mathrm{~A}$ and $\mathrm{C}_{4} \mathrm{~A}_{3}$

2.2.5 The $\mathrm{CaO}-\mathrm{Al}_{2} \mathrm{O}_{3}-\mathrm{SiO}_{2}$ system 33

2.2.6 Clinker formation in the $\mathrm{CaO}-\mathrm{Al}_{2} \mathrm{O}_{3}-\mathrm{SiO}_{2}$ system 35

2.3 Systems containing $\mathrm{Fe}_{2} \mathrm{O}_{3}$

2.3.1 The $\mathrm{CaO}-\mathrm{Al}_{2} \mathrm{O}_{3}-\mathrm{Fe}_{2} \mathrm{O}_{3}$ system 36

2.3.2 The $\mathrm{CaO}-\mathrm{Al}_{2} \mathrm{O}_{3}-\mathrm{Fe}_{2} \mathrm{O}_{3}-\mathrm{SiO}_{2}$ system 38

2.3.3 Clinker formation in the $\mathrm{CaO}-\mathrm{Al}_{2} \mathrm{O}_{3}-\mathrm{Fe}_{2} \mathrm{O}_{3}-\mathrm{SiO}_{2}$ system 40

2.4 Systems containing $\mathrm{MgO}$ or $\mathrm{FeO}$

2.4.1 General 42

2.4.2 Effect of $\mathrm{MgO}$ on equilibria in the $\mathrm{CaO}-\mathrm{Al}_{2} \mathrm{O}_{3}-\mathrm{Fe}_{2} \mathrm{O}_{3}-\mathrm{SiO}_{2}$ system 43

2.4.3 Phases structurally related to gehlenite 45

2.5 Systems containing alkalis or $\mathrm{SO}_{3}$ or both 46

2.5.1 Phases 46

$\begin{array}{ll}\text { 2.5.2 Equilibria } & 49\end{array}$

2.6 Systems with other components $\quad 50$

2.6.1 Fluorides and fluorosilicates 50

2.6.2 Carbonates 52

2.7 Laboratory preparation of high-temperature phases 52

3 The chemistry of Portland cement manufacture 55

3.1 General considerations $\quad 55$

3.1.1 Summary of the reactions in clinker formation 55

3.1.2 Lime saturation factor, silica ratio and alumina ratio 56

3.1.3 The Bogue calculation 57

3.1.4 Enthalpy changes in clinker formation 58

3.2 Raw materials and manufacturing processes 60

3.2.1 Raw materials and fuel $\quad 60$

3.2.2 Dry and wet processes; energy requirements 61

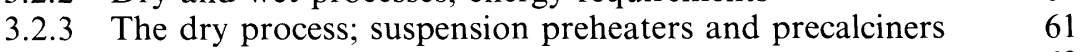

3.2.4 The rotary kiln 63

3.2.5 Circulation of volatiles; dust; cooling of clinker 64

3.2.6 Other processes for clinker production; clinker grinding 64 
3.3 Reactions below about $1300^{\circ} \mathrm{C}$

3.3.1 Decomposition of carbonate minerals 65

3.3.2 Decomposition of clay minerals and formation of products 66

3.3.3 Sampling from cement kilns or preheater outlets 67

3.3.4 Reaction mechanisms 68

3.3.5 Condensation or reaction of volatiles 69

3.4 Reactions at $1300-1450^{\circ} \mathrm{C} \quad 70$

3.4.1 Quantity of liquid formed 70

3.4.2 Burnabilities of raw mixes $\quad 72$

3.4.3 Nodulization $\quad 74$

3.4.4 Formation and recrystallization of alite $\quad 74$

3.4.5 Evaporation of volatiles; polymorphic transitions 75

3.4.6 Effects of reducing conditions; colour of clinker 76

3.5 Reactions during cooling, grinding or storage 77

3.5.1 Solidification of the clinker liquid: indications from
pure systems

3.5.2 Do Portland cement clinkers contain glass or $\mathrm{C}_{12} \mathrm{~A}_{7}$ ? 77

3.5.3 Evidence from X-ray microanalysis 79

3.5.4 Effects of cooling rate on the aluminate and ferrite phases $\quad 79$

3.5.5 Other effects of cooling rate 80

3.5.6 Crystallization of the sulfate phases 81

3.5.7 Quantitative estimation of the distributions of alkalis and $\mathrm{SO}_{3}$ between phases $\quad 81$

3.5.8 Changes during grinding or storage 84

3.6 Effects of minor components 84

3.6.1 General 84

3.6.2 Effects of s-block elements 85

3.6.3 Effects of p- and d-block elements 86

4 Properties of Portland clinker and cement 89

4.1 Macroscopic and surface properties $\quad 89$

4.1.1 Unground clinker 89

4.1.2 Particle size distribution of ground clinker or cement $\quad 89$

4.1.3 Specific surface area determination 91

4.1.4 Particle size distribution, phase composition and
cement properties

$\begin{array}{ll}\text { 4.1.5 Chemical analysis } & 93\end{array}$

4.2 Light microscopy 93

4.2.1 General 93

4.2.2 Effects of bulk composition, raw feed preparation and
ash deposition

4.2.3 Effects of burning conditions and cooling rate 95

4.2.4 Applications of light microscopic investigations 96 
4.3 Scanning electron microscopy, X-ray diffraction and other techniques $\quad 97$

4.3.1 Scanning electron microscopy 97

4.3.2 X-ray diffraction $\quad 99$

4.3.3 Chemical or physical methods for separation of phases $\quad 100$

$\begin{array}{ll}\text { 4.3.4 Other methods } & 102\end{array}$

4.4 Calculation of quantitative phase composition from bulk chemical analysis $\quad 102$

$\begin{array}{lll}4.4 .1 & \text { General } & 102\end{array}$

$\begin{array}{ll}\text { 4.4.2 Modified Bogue calculation } & 102\end{array}$

$\begin{array}{lll}\text { 4.4.3 Mass balance calculations } & 104\end{array}$

$\begin{array}{ll}\text { 4.4.4 Limitations and modifications of the modified } & 104 \\ \text { Bogue calculation } & 104\end{array}$

4.5 Physical methods for determining quantitative phase composition $\quad 106$

$\begin{array}{lll}\text { 4.5.1 General } & 106\end{array}$

$\begin{array}{lll}\text { 4.5.2 Light microscopy } & 106\end{array}$

4.5.3 Quantitative X-ray diffraction analysis (QXDA) 106

$\begin{array}{ll}\text { 4.5.4 Comparison of results of different methods } & 108\end{array}$

$\begin{array}{lr}\text { 4.6 Reactivities of clinker phases } & 109\end{array}$

$\begin{array}{lll}\text { 4.6.1 Effect of major compositional variation } & 109\end{array}$

4.6.2 Effects of ionic substitutions, defects and variation
in polymorph

4.6.3 Ferrite reactivity; effect of complexing in solution 112

5 Hydration of the calcium silicate phases 113

$\begin{array}{ll}5.1 \text { Introduction } & 113\end{array}$

$\begin{array}{lll}\text { 5.1.1 Definitions and general points } & 113\end{array}$

$\begin{array}{ll}\text { 5.1.2 Experimental considerations; carbonation } & 114\end{array}$

$\begin{array}{ll}\text { 5.1.3 Calcium hydroxide } & 116\end{array}$

5.2 Composition, density and other data for $\mathrm{C}-\mathrm{S}-\mathrm{H}$ gel $\quad 118$

5.2.1 Calcium hydroxide content, thermal analysis and indirect $\begin{array}{ll}\text { determination of the } \mathrm{Ca} / \mathrm{Si} \text { ratio } & 118\end{array}$

$\begin{array}{ll}\text { 5.2.2 Water content } & 119\end{array}$

$\begin{array}{lll}\text { 5.2.3 Density and infrared spectra } & 121\end{array}$

5.3 Microstructure, microanalysis and electron diffraction 123

$\begin{array}{lll}\text { 5.3.1 Microstructure } & 123\end{array}$

$\begin{array}{lll}\text { 5.3.2 Stages in microstructural development } & 123\end{array}$

$\begin{array}{ll}\text { 5.3.3 X-ray microanalysis } & 126\end{array}$

$\begin{array}{ll}\text { 5.3.4 Analytical electron microscopy } & 127\end{array}$

$\begin{array}{ll}\text { 5.3.5 Electron diffraction } & 128\end{array}$ 
5.4 More highly ordered phases related to $\mathrm{C}-\mathrm{S}-\mathrm{H}$ gel 128

5.4.1 General 128

$\begin{array}{lll}5.4 .2 & 1.4 \mathrm{~nm} \text { tobermorite } & 129\end{array}$

5.4.3 Jennite 131

5.4.4 C-S-H(I) 132

5.4.5 Products formed in suspensions from $\mathrm{C}_{3} \mathrm{~S}$ or
$\beta-\mathrm{C}_{2} \mathrm{~S} ; \mathrm{C}-\mathrm{S}-\mathrm{H}(\mathrm{II})$

5.5 Silicate anion structure $\quad 134$

5.5.1 Introduction 134

5.5.2 C-S-H gel of calcium silicate or cement pastes: chemical methods 135

5.5.3 C-S-H gel of calcium silicate or cement pastes: nuclear
magnetic resonance

5.5.4 $\mathrm{C}-\mathrm{S}-\mathrm{H}(\mathrm{I})$ and other products made in suspension 138

5.6 The nanostructures of $C-S-H$ gel and related materials $\quad 140$

5.6.1 Broad features and tobermorite-based models
for C-S-H(I)

5.6.2 Tobermorite-based models for the $\mathrm{C}-\mathrm{S}-\mathrm{H}$ of calcium
silicate and cement pastes

5.6.3 A mixed tobermorite-jennite model for the $\mathrm{C}-\mathrm{S}-\mathrm{H}$ of calcium silicate and cement pastes

5.6.4 Other models for the C-S-H of calcium silicate and cement pastes

\subsection{Equilibria}

5.7.1 Solubility relations 145

5.7.2 Species in solution 147

5.7.3 Thermochemistry and thermodynamics 148

$\begin{array}{ll}\text { 5.7.4 Effects of alkalis and of gypsum } & 149\end{array}$

5.8 Kinetics and mechanisms $\quad 150$

$\begin{array}{lll}5.8 .1 & \mathrm{C}_{3} \mathrm{~S} \text { : experimental data } & 150\end{array}$

5.8.2 $\mathrm{C}_{3} \mathrm{~S}$ : the initial reaction 153

5.8.3 $\mathrm{C}_{3} \mathrm{~S}$ : the induction period 153

5.8.4 The main reaction $\left(\mathrm{C}_{3} \mathrm{~S}\right.$ and $\left.\beta-\mathrm{C}_{2} \mathrm{~S}\right) \quad 155$

5.8.5 Early hydration of $\beta-\mathrm{C}_{2} \mathrm{~S} \quad 156$

6 Hydrated aluminate, ferrite and sulfate phases $\quad 157$

$6.1 \mathrm{AFm}$ phases 157

6.1.1 Compositional and structural principles $\quad 157$

6.1.2 The $\mathrm{C}_{4} \mathrm{AH}_{x}, \mathrm{C}_{4} \mathrm{AC}_{0.5} \mathrm{H}_{x}$ and $\mathrm{C}_{4} \mathrm{~A} \overline{\mathrm{C}} \mathrm{H}_{x}$ phases 159

6.1.3 The $\mathrm{C}_{4} \mathrm{~A} \overline{\mathrm{S}} \mathrm{H}_{x}$ phases 161

6.1.4 Other AFm phases containing aluminium 161

6.1.5 AFm phases containing iron 164

6.1.6 XRD patterns, thermal behaviour, optical properties
and IR spectra 
6.2 AFt phases 166

6.2.1 Compositions and crystal structures 166

6.2.2 Ettringite analogues and solid solutions 168

$\begin{array}{lll}6.2 .3 & \text { Properties } & 169\end{array}$

6.3 Other hydrated phases $\quad 170$

6.3.1 Hydrogarnet phases $\quad 170$

6.3.2 $\mathrm{CAH}_{10} \quad 171$

6.3.3 Brucite, hydrotalcite and related phases 173

$\begin{array}{lll}\text { 6.3.4 Sulfate phases } & 174\end{array}$

6.4 Equilibria and preparative methods 176

6.4.1 The $\mathrm{CaSO}_{4}-\mathrm{H}_{2} \mathrm{O}, \mathrm{CaSO}_{4}-\mathrm{Ca}(\mathrm{OH})_{2}-\mathrm{H}_{2} \mathrm{O}$ and
$\mathrm{CaSO}_{4}-\mathrm{K}_{2} \mathrm{SO}_{4}-\mathrm{H}_{2} \mathrm{O}$ systems

6.4.2 The $\mathrm{CaO}-\mathrm{Al}_{2} \mathrm{O}_{3}-\mathrm{H}_{2} \mathrm{O}$ and $\mathrm{CaO}-\mathrm{Al}_{2} \mathrm{O}_{3}-\mathrm{SO}_{3}-\mathrm{H}_{2} \mathrm{O}$ systems 177

6.4.3 Systems including $\mathrm{Na}_{2} \mathrm{O}, \mathrm{K}_{2} \mathrm{O}, \mathrm{SiO}_{2}, \mathrm{CaCO}_{3}$ or $\mathrm{CaCl}_{2} \quad 180$

6.4.4 Preparative methods 181

6.5 Hydration reactions of the aluminate and ferrite phases 182

6.5.1 Reaction of $\mathrm{C}_{3} \mathrm{~A}$ with water or with water and calcium hydroxide

6.5.2 Reaction of $\mathrm{C}_{3} \mathrm{~A}$ with water in the presence of calcium sulfate $\quad 182$

6.5.3 Effects of temperature, alkali, tricalcium silicate and $\mathrm{CO}_{2} \quad 184$

6.5.4 Reaction of the ferrite phase $\quad 184$

6.5.5 Enthalpy changes 186

7 Hydration of Portland cement 187

7.1 Evidence from $X$-ray diffraction, thermal analysis and
infrared spectroscopy

7.1.1 Introduction; formation of calcium hydroxide and C-S-H 187

7.1.2 Formation of hydrated aluminate or sulfoaluminate phases 188

7.1.3 Evidence from differential thermal analysis and infrared spectroscopy 189

7.2 Microstructure 191

7.2.1 Evidence from light and electron microscopy 191

7.2.2 The early period of hydration 193

7.2.3 The middle period of hydration 195

$\begin{array}{ll}\text { 7.2.4 The late period of hydration } & 196\end{array}$

7.3 Analytical data for cement pastes 197

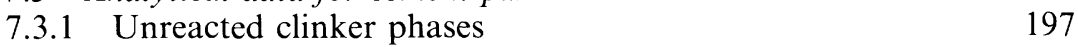

7.3.2 Non-evaporable and bound water 197

7.3.3 Thermogravimetry and calcium hydroxide content 199

7.3.4 Hydrated aluminate and silicate phases 201

7.3.5 Analyses of individual phases 201

$\begin{array}{lll}\text { 7.3.6 Silicate anion structure } & 204\end{array}$ 
7.4 Interpretation of analytical data 205

7.4.1 Substitution or admixed phases? 205

7.4.2 $\mathrm{Fe}_{2} \mathrm{O}_{3}$ in cement hydration products 207

7.4.3 $\mathrm{MgO}, \mathrm{SO}_{3}$ and alkalis in cement hydration products 208

7.4.4 The stoichiometry of cement hydration 209

7.5 Calorimetry, pore solutions and energetics 212

7.5.1 The early and middle periods 212

7.5.2 Pore solutions after the first day 214

7.5.3 Energetics of cement hydration 215

7.6 Actions of calcium sulfate and of alkalis 218

$\begin{array}{lll}7.6 .1 & \text { Setting } & 218\end{array}$

7.6.2 Optimum gypsum 219

7.6.3 Effects of alkalis 221

7.7 Kinetics and modelling of the hydration process 222

7.7.1 Experimental data 222

7.7.2 Interpretation of kinetic data 224

8 Structure and properties of fresh and hardened Portland cement pastes

$8.1 \quad$ Fresh pastes 227

8.1.1 Workability 227

8.1.2 Rheology; viscometry 227

8.1.3 Oscillatory and controlled-stress rheometry 229

8.1.4 Models of fresh paste structure 230

8.2 Hardened cement pastes: models of structure 231

8.2.1 The Powers-Brownyard model 231

8.2.2 Minimum water/cement ratio for complete hydration; chemical shrinkage 232

8.2.3 Calculation of volumetric quantities 234

8.2.4 Later models of cement gel structure 235

8.3 Mathematical modelling of microstructure and properties 237

8.3.1 Introduction 237

8.3.2 Calculation of porosities and of volume fractions of
solid phases

8.3.3 Microstructural models 242

8.4 Experimental methods for studying pore structure 243

8.4.1 General points 243

8.4.2 Determination of porosities by pyknometry 243

8.4.3 Sorption isotherms; specific surface areas 244

8.4.4 Pore size distributions 246

8.4.5 Mercury intrusion porosimetry (MIP) 247

8.4.6 Scanning electron microscopy 249

8.4.7 AC impedance spectroscopy 249

$\begin{array}{ll}\text { 8.4.8 Other methods } & 251\end{array}$ 
8.5 Strength

8.5.1 Empirical relations between compressive strength and porosity

8.5.2 Relations between strength and microstructure or pore size distribution

8.5.3 Mechanisms of failure

8.7. Permeability and diffusion 258

8.7.1 Permeability to water 258

$\begin{array}{ll}\text { 8.7.2 Diffusion of ions and gases } & 259\end{array}$

9 Composite cements 261

9.1 Introduction 261

9.2 Blastfurnace slag 262

9.2.1 Formation, treatment and use in composite cements 262

9.2.2 Factors affecting suitability for use in a composite cement 263

9.2.3 X-ray diffraction and microstructure of slags 264

9.2.4 Internal structures of slag glasses 265

9.2.5 Hydration chemistry of slag cements 266

9.2.6 X-ray microanalysis $\quad 267$

9.2.7 Stoichiometry of slag cement hydration 270

9.2.8 Activation of slag glasses 271

9.2.9 Alkali-activated slag cements 271

9.2.10 Supersulfated cements 272

9.3 Flyash (pulverized fuel ash) low in $\mathrm{CaO}$

$\begin{array}{ll}\text { 9.3.1 Properties } & 272\end{array}$

9.3.2 Factors governing suitability for use in composite cements 274

9.3.3 Rates of consumption of clinker phases and flyash, and contents of calcium hydroxide 275

9.3.4 Microstructure and compositions of the hydration products 277

9.3.5 Stoichiometry of flyash cement hydration 279

9.3.6 The nature of the pozzolanic reaction 280

9.4 Natural pozzolanas 280

9.4.1 Properties 280

9.4.2 Hydration reactions 281

9.5 Silica fume (condensed silica fume, microsilica) 284

9.5.1 Properties 284

9.5.2 Hydration reactions 285 
9.6 Other mineral additions 286

9.6.1 Class C flyash 286

9.6.2 Other pozzolanic or hydraulic additions 288

9.6.3 Calcium carbonate and other mineral additions 289

9.7 Pore structures and their relation to physical properties 290

9.7.1 Calculated porosities for pastes containing slag or flyash 290

9.7.2 Modelling of pore structure 290

9.7.3 Experimental determination of porosities and pore size distributions 291

9.7.4 Relations between pore structure and physical properties 293

10 Calcium aluminate, expansive and other cements 295

10.1 Calcium aluminate cements 295

10.1.1 Introduction 295

10.1.2 Manufacture; chemical and mineralogical compositions 295

10.1.3 Reactivities of the phases and methods of studying hydration 298

10.1.4 Hydration reactions and products 298

10.1.5 Thermodynamic calculations 301

10.1.6 Setting times; mixing and placing 303

10.1.7 Microstructural development 304

10.1.8 Hardening; effects of conversion 306

10.1.9 Chemical admixtures 309

10.1.10 Mixtures with calcite, slag, gypsum or Portland cement 310

10.1.11 Reactions of calcium aluminate cement concrete with external agents 311

10.1.12 Refractory castables 312

10.2 Expansive cements 313

10.2.1 General 313

10.2.2 Types of expansive cement 314

10.2.3 Mechanism of expansion in Type K cements 315

10.3 Other cements 317

10.3.1 Very rapidly hardening cements 317

10.3.2 Energy reduction in the manufacture of cements 319

$\begin{array}{lll}\text { 10.3.3 Reactive belites } & 320\end{array}$

10.3.4 Cements containing belite and a highly reactive
constituent

$\begin{array}{lll}\text { 10.3.5 Alinite cements } & 321\end{array}$

11 Admixtures and special uses of cements 323

11.1 Introduction 323

11.2 Organic retarders and accelerators 323

11.2.1 Retarders 323

11.2.2 Mechanism of retardation 324

$\begin{array}{ll}11.2 .3 & \text { Practical retarders } \\ 11.2 .4 & 327\end{array}$

$\begin{array}{lll}11.2 .4 & \text { Organic accelerators } & 328\end{array}$ 
$\begin{array}{ll}\text { 11.3 Air-entraining agents and grinding aids } & 328\end{array}$

$\begin{array}{ll}\text { 11.3.1 Air-entraining agents } & 328\end{array}$

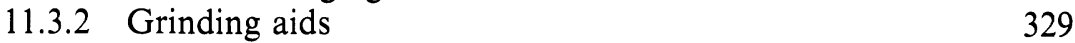

11.4 Water reducers and superplasticizers $\quad 330$

$\begin{array}{ll}11.4 .1 \quad \text { Water reducers } & 330\end{array}$

$\begin{array}{lll}\text { 11.4.2 Superplasticizers } & 330\end{array}$

11.4.3 Mode of action of water reducers and superplasticizers $\quad 332$

11.4.4 Zeta potential, rheology and nature of the sorbent phases 333

11.4.5 Reasons for the enhanced dispersing power of superplasticizers $\quad 334$

11.5 Inorganic accelerators and retarders 334

11.5.1 Accelerators of setting and hardening 334

11.5.2 Mode of action 335

11.5.3 Effects on the composition and structure of the
hydration products

11.5.4 Precipitation effects; inorganic retarders and setting 338

11.6 Effects of high or low temperatures at atmospheric pressure 339

11.6.1 Hydration at $25-100^{\circ} \mathrm{C} \quad 339$

11.6.2 Effects on kinetics, ultimate extent of hydration and
microstructure

$\begin{array}{lll}\text { 11.6.3 Low temperatures } & 341\end{array}$

11.7 High-pressure steam curing $\quad 341$

$\begin{array}{lll}11.7 .1 & \text { General } & 341\end{array}$

$\begin{array}{lll}\text { 11.7.2 Basic chemistry of autoclave processes } & 342\end{array}$

11.7.3 Mechanisms of reaction and equilibria 344

11.7.4 Characteristics of hydrothermally formed C-S-H
and tobermorite

11.8 Oil well cementing $\quad 346$

$\begin{array}{lll}11.8 .1 \text { General } & 346\end{array}$

11.8.2 Types of cement and of admixture $\quad 346$

11.8.3 Effects of temperature and pressure 348

11.9 Very high strength cement-based materials 348

$\begin{array}{lll}11.9 .1 & \text { General } & 348\end{array}$

$\begin{array}{lll}11.9 .2 & \text { DSP concretes } & 349\end{array}$

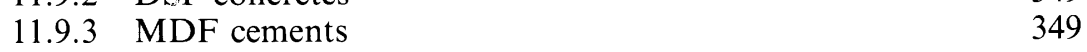

12 Concrete chemistry $\quad 351$

12.1 Cement paste in concrete 351

12.1.1 The interfacial transition zone 351

12.1.2 Backscattered electron imaging of the interfacial
transition zone

$x v i$ 
12.1.3 The nature of the paste-aggregate bond 354

12.1.4 Permeability of the interfacial transition zone 354

12.1.5 Composite cements and other topics 354

12.1.6 Effects at exposed surfaces 355

12.2 Durability: general aspects 356

12.3 Carbonation, chloride penetration and corrosion of reinforcement 356

12.3.1 General 356

12.3.2 Carbonation 357

12.3.3 Transport and reactions of chlorides $\quad 359$

12.3.4 Corrosion $\quad 360$

12.4 Alkali silica reaction 361

12.4.1 General 361

12.4.2 Chemistry of alkali silica reaction 363

12.4.3 The expansion process 366

12.4.4 ASR in mortars or concretes made with

12.5 Sulfate attack 368

12.5.1 General 368

12.5.2 Sodium sulfate solutions 370

12.5.3 Magnesium sulfate solutions $\quad 370$

12.5.4 Calcium sulfate 371

12.5.5 Composite cements and sulfate attack 371

12.5.6 Mechanisms of weakening and expansion 372

12.5.7 Reactions involving sulfate and carbonate 373

12.6 Delayed ettringite formation 374

12.6.1 Conditions of occurrence 374

12.6.2 Decomposition and reformation of ettringite and the
origin of expansion

12.6.3 Effects of variation in the cement 377

12.6.4 Effects of aggregate and other factors 378

12.7 Other forms of attack 379

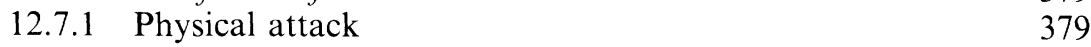

$\begin{array}{lll}12.7 .2 & \text { Leaching } & 380\end{array}$

12.7.3 Miscellaneous forms of chemical attack 381

12.7.4 Sea water attack 382

12.7.5 Bacterial attack 382

12.7.6 Miscellaneous paste-aggregate reactions 383

12.7.7 Fire damage 384 
Cement chemistry

Appendix: Calculated X-ray powder diffraction patterns for tricalcium silicate and clinker phases

References

393

Index

439

xviii 